\title{
The Optimization of Sintering Conditions for the Preparation of Ti-Al-Si Alloys
}

\author{
Anna Knaislová ${ }^{1}$, Vendula Šimůnková ${ }^{\text {, Pavel Novák }}{ }^{1}$, Filip Průša ${ }^{1}$, Sławomir Cygan ${ }^{2}$, Lucyna Jaworska ${ }^{2}$ \\ ${ }^{1}$ Department of Metals and Corrosion Engineering, University of Chemistry and Technology Prague. Technická 5, 16628 \\ Prague. Czech Republic. E-mail: knaisloa@vscht.cz \\ ${ }^{2}$ The Institute of Advanced Manufacturing Technology. Wroclawska 37A, 30-011 Krakow. Poland
}

This work deals with optimization of Spark Plasma Sintering conditions for the preparation of Ti-Al-Si alloys. TiAl-Si alloys are appropriate material for high-temperature applications, especially for aerospace and automotive industry. They are characterized by low density, good mechanical properties and resistance against oxidation. TiAl-Si alloys were prepared by powder metallurgy using reactive sintering, followed by milling and Spark Plasma Sintering. Preparation of intermetallic compounds is complicated due to high melting points of intermediate phases, the exothermic reaction during their formation and high reactivity of the melt with melting crucible. TiAl10Si20 alloy was prepared by Spark Plasma Sintering under a pressure of $48 \mathrm{MPa}$ and by High Pressure Spark Plasma Sintering under pressure of $6 \mathrm{GPa}$. The temperature was chosen between $1100{ }^{\circ} \mathrm{C}$ and $1204{ }^{\circ} \mathrm{C}$. The porosity of TiAl10Si20 alloy decreases with pressure and with the high pressure also increases the hardness by 200 HV 5. Abrasive wear resistance of TiAl10Si20 alloy is very good.

Keywords: Intermetallics, Powder Metallurgy, Spark Plasma Sintering, High Pressure Spark Plasma Sintering

\section{Acknowledgement}

The research was supported by Czech Science Foundation, project No. P108/12/G043.

\section{References}

[1] DADLEZ, R.,JAROSZEWSKI, W. (1994). Tektonika. Wysawnictwo Naukowe PWN, Warszawa

[2] KIMURA, Y.,POPE, D.P. (1998). Ductility and toughness in intermetallics. In: Intermetallics, Vol. 6, No. 7-8, pp. 567-571.

[3] RAO, K.P.,ZHOU, J.B. (2002). Characterization of mechanically alloyed Ti-Al-Si powder blends and their subsequent thermal stability. In: Materials Science and Engineering: A, Vol. 338, No. 1-2, pp. 282-298.

[4] KNAISLOVÁ, A., NOVÁK, P.,PRŮŠA, F. (2016). Preparation of Ti-Al-Si alloys by powder metallurgy. In: Manufacturing Technology, Vol. in press.

[5] KNAISLOVÁ, A., NOVÁK, P.,NOVÁ, K. (2016). Using of Microscopy in optimization of the Ti-Al-Si alloys preparation by powder metallurgy. In: Manufacturing Technology, Vol. in press.

[6] VOJTĚCH, D., MORT'ANIKOVÁ, M.,NOVÁK, P. (2007). Kinetic and Thermodynamic Aspects of High-Temperature Oxidation of Selected Ti-Based Alloys. In: Defect and Diffusion Forum, Vol. 263, 123-128.

[7] GUAN, Z.Q., PFULLMANN, T., OEHRING, M.,BORMANN, R. (1997). Phase formation during ball milling and subsequent thermal decomposition of Ti-Al-Si powder blends. In: Journal of Alloys and Compounds, Vol. 252, No. 1-2, pp. 245-251.

[8] WU, J.S., BEAVEN, P.A.,WAGNER, R. (1990). The Ti3(Al, Si) + Ti5(Si, Al)3 Eutectic Reaction in the Ti-Al-Si system. In: Scripta Metallurgica et Materialia, Vol. 24, No. 1, pp. 207-212.

[9] NOVÁK, P. (2012). Příprava, vlastnosti a použití intermetalických sloučenin. In: Chemické listy, Vol. 106, 884889.

[10] NOVÁK, P., VOJTĚCH, D., ŠERÁK, J., KUBÁSEK, J., PRŮŠA, F., KNOTEK, V., MICHALCOVÁ, A.,NOVÁK, M. (2009). Syntéza intermediálních fází systému Ti-Al-Si metodou reaktivní sintrace. In: Chemické listy, Vol. 103, 1022-1026.

[11] MACEK, K., ZUNA, P.,JANOVEC, J. (2008). Tepelné zpracování kovových materiálio. Vyd. 1. ed. České vysoké učení technické, Praha

[12] TSUKERMAN, S.A., INTRODUCTION, in Powder Metallurgy. 1965, Pergamon. p. vii-xi.

[13] NOVÁK, P., MICHALCOVÁ, A., MAREK, I., VODĚROVÁ, A.,VOJTĚCH, D. (2012). Possibilities of the observation of chemical reactions during the preparation of intermetallics by reactive sintering. In: Manufacturing Technology, Vol. 12, No. 13, pp. 197-201.

[14] VALALÍK, M., NOVÁK, P., KUBATÍK, T.F.,VOJTĚCH, D. (2015). Unconventional Method of Preparation Intermetallic Phases Fe-Al by Mechanical Alloying in Comparison to Reactive Sintering. In: Manufacturing Technology, Vol. Vol. 15, No. No. 1, pp. 105-109. 
[15] MUNIR, Z.A., ANSELMI-TAMBURINI, U.,OHYANAGI, M. (2006). The effect of electric field and pressure on the synthesis and consolidation of materials: A review of the spark plasma sintering method. In: Journal of Materials Science, Vol. 41, No. 3, pp. 763-777.

[16] SUÁREZ, M., FERNÁNDEZ, A., MENÉNDEZ, J.L., TORRECILlAS, R., KESSEL, H.U., HENNICKE, J., KIRCHNER, R.,KESSEL, T. (2013). Challenges and Opportunities for Spark Plasma Sintering: A Key Technology for a New Generation of Materials. In: InTech open access, Vol.

[17] ZHANG, Z.-H., LIU, Z.-F., LU, J.-F., SHEN, X.-B., WANG, F.-C.,WANG, Y.-D. (2014). The sintering mechanism in spark plasma sintering - Proof of the occurrence of spark discharge. In: Scripta Materialia, Vol. 81, 5659.

[18] LICHERI, R., ORRÙ, R., MUSA, C., LOCCI, A.M.,CAO, G. (2009). Consolidation via spark plasma sintering of $\mathrm{HfB} 2 / \mathrm{SiC}$ and $\mathrm{HfB} 2 / \mathrm{HfC} / \mathrm{SiC}$ composite powders obtained by self-propagating high-temperature synthesis. In: Journal of Alloys and Compounds, Vol. 478, No. 1-2, pp. 572-578.

[19] LICHERI, R., MUSA, C., ORRÙ, R.,CAO, G. (2015). Influence of the heating rate on the in situ synthesis and consolidation of $\mathrm{ZrB} 2$ by reactive Spark Plasma Sintering. In: Journal of the European Ceramic Society, Vol. 35, No. 4, pp. 1129-1137.

[20] LAgOS, M.A., AGOTE, I., ATXAGA, G., ADARRAGA, O.,PAMBAGUIAN, L. (2016). Fabrication and characterisation of Titanium Matrix Composites obtained using a combination of Self propagating High temperature Synthesis and Spark Plasma Sintering. In: Materials Science and Engineering: A, Vol. 655, 44-49.

[21] NOVÁK, P., VOJTĚCH, D., ŠERÁK, J.,KNOTEK, V. (2005). Vliv složení nitridační atmosféry na strukturu a vlastnosti plazmově nitridované PM nástrojové oceli legované niobem. In: Metal, Vol. 